\title{
The Effect of Organizational Culture, Career Development and Competence in the Pandemic Era on Job Satisfaction Its Implications on Employee Performance at PT Wijaya Karya Rekaya Konstruksi
}

\author{
Eko Susilo Prayitno ${ }^{1}$, Cicih Ratnasih ${ }^{2}$, Pudji Astuty ${ }^{3}$ \\ \{espanti@yahoo.com¹, Cicih_ratnasih@borobudur.ac.id², puji_astuty@borobudur.ac.id $\left.{ }^{3}\right\}$ \\ Universitas Borobudur, Jakarta, Indonesia ${ }^{1,2,3}$
}

\begin{abstract}
PT Wijaya Karya Rekayasa Konstruksi (WIKA REKON) in the Pandemic Era: The Impact of Organizational Culture, Career Development, and Competence on Job Satisfaction with Implications on Employee Performance, Borobudur University, Jakarta. In the aftermath of the pandemic, this study investigates the direct and indirect effects of organizational culture, career development, and competency characteristics on job satisfaction, as well as the consequences for employee performance. These factors include culture, career and competence which in this study functioned as independent variables to predict their relationship with Employee Satisfaction and Performance which is the dependent variable. The research sample was 120 employees of PT Wijaya Karya Rekayasa Konstruksi from various levels of position. Organizational culture has a direct beneficial influence on employee performance, according to data analysis tool SEM (Structural Equation Modeling). Employee satisfaction and performance are directly influenced by career development. Companies must focus on aligning organizational culture factors, developing employee careers and increasing competence in company dynamics in this pandemic era so that company interests and goals can be achieved.
\end{abstract}

Keywords: Organizational Culture; Pandemic Era; Employee Satisfaction; Employee Performance; Employee Competence; Career Development

\section{Introduction}

COVID-19 is an important disease outbreak in global public health in 2020. The majority of developing countries will experience more obstacles than developed countries in restraining the rate of transmission of COVID-19, so that it has the potential to develop into a new epicenter, including Indonesia (Hopman et al., 2020. Companies must operate more effectively and efficiently in the face of competition in the pandemic age. Companies must be able to boost their competitiveness in order to stay afloat in the face of ever-increasing competition. PT WIjaya Karya Rekayasa Konstruksi is one of the Indonesian construction businesses that has a policy of optimizing its employees' production business operations. 
The publishers are inclined to focus on "The Impact of Organizational Behavior, Career Progression, and Expertise in the Pandemic Era on Employee Satisfaction and Its Implications on Job Performance at PT. Wijaya Karya Construction Engineering (Wika -Rekon)" based on the above description. The phenomenon that occurred at PT Wijaya Karya Rekayasa Konstruksi, as a first step in researching a number of employees, shows a number of problems that need attention. The primary difficulties in this study were framed as follows, based on the context of the problems that occurred:

a. The achievement of organizational targets has not been maximized in the Pandemic Era

b. Low awareness of the work of employees for the organization (Demotivation)

c. The level of discipline and motivation that tends to decrease

d. The lack of clarity of goals and policies implemented by the organization

\section{Research Purposes}

The goal of this study is to test hypotheses and expose empirical facts as follows, based on the description of the problem given in Chapter I:

a. To study the direct effect Organizational Culture on Job Satisfaction of PT Wijaya Karya Engineering Construction Employees in the Pandemic Era.

b. To study the direct effect Career Development on Job Satisfaction of PT Wijaya Karya Engineering Construction Employees in the Pandemic Era.

c. To study the direct effect Work Competence on Job Satisfaction of PT Wijaya Karya Engineering Construction Employees in the Pandemic Era.

d. To study the indirect effect Organizational Culture on Employee Performance of PT Wijaya Karya Rekayasa Konstruksi in the Pandemic Era.

e. To study the indirect effect Career Development on Employee Performance of PT Wijaya Karya Engineering Construction in the Pandemic Era.

f. To examine the indirect effect of Competence on the Performance of PT Wijaya Karya Engineering Construction Employees in the Pandemic Era.

g. To study the direct effect Job Satisfaction on the Performance of PT Wijaya Karya Engineering Construction employees in the Pandemic Era.

Based on relevant research, the researcher found that not many researchers have researched Career Development and Employee Competence. This is the novelty of this research, where Career Development and Employee Competence as moderating variables influence Organizational Culture and Employee Satisfaction in the Pandemic Era on Employee Performance of PT Wijaya Karya Rekayasa Konstruksi.

\section{Thinking Framework}

Based on the concepts or theories above, in this discussion the framework of thinking in the analytical model is presented as follows: 


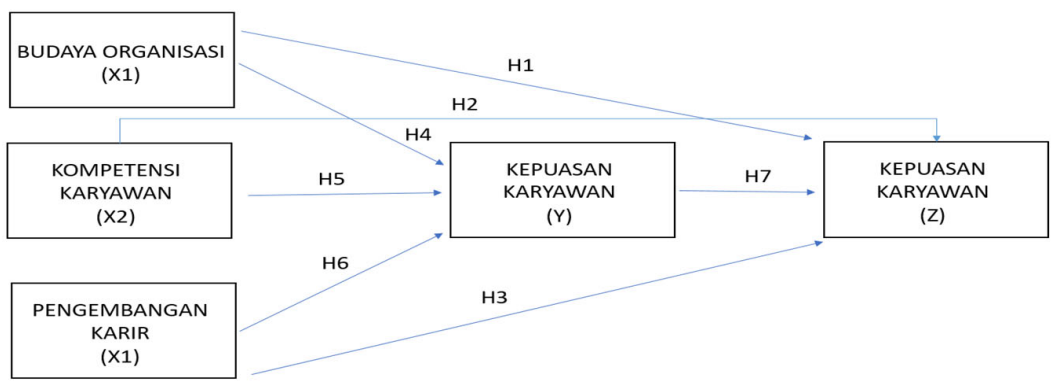

Based on the theoretical description and framework of thinking above, in this study the following hypothesis is proposed:

$\mathrm{H} 1=$ Employee Performance is directly influenced by organizational culture.

$\mathrm{H} 2=$ Customer Competency influences employee directly.

$\mathrm{H} 3=$ Worker Productivity is closely influenced by employee career development.

$\mathrm{H} 4=$ Performance Is influenced by organizational culture in an indirect way.

$\mathrm{H} 5=$ Worker Expertise influences employee in a roundabout way.

H6 $=$ Worker Professional Growth has a direct impact on employee productivity.

$\mathrm{H} 7=$ Worker satisfaction has a strong correlation with employee productivity.

\section{Methodology}

The method utilized in this study is a quantitative technique, which involves examining the numbers acquired in order to determine the extent of the link here between variables analyzed. The information utilized in this study was divided into two categories:

a) Primary data, primary data is information gathered directly from respondents, namely PT Wijaya Karya Rekayasa Konstruksi workers.

b) Secondary data, data that has been processed and provided by primary data collectors or other parties is referred to as secondary data. namely PT Wijaya Karya Rekayasa Konstruksi and other sources that support the analysis of this research such as books, articles, and other relevant publications.

In order to collect the primary and secondary data, the researcher carried out the following techniques:

a) Questionnaire, the questionnaire was designed to obtain the required data from the respondents, namely the employees of PT Wijaya Karya Rekayasa Konstruksi. The statements in the questionnaire have been designed in such a way that they do not deviate from the research objectives. In this questionnaire used a Likert scale model measurement scale with a scale range of 1 to 5 .

b) Study of literature, literature studies are carried out by studying and collecting data needed in research as well as from other sources relevant to the research problem, such as libraries, internet and discussion forums. 


\section{Results and Discussion}

Based on the conceptual framework of the research that has been stated previously, this study has several hypotheses $\mathrm{HO}$ and $\mathrm{Ha}$ from each variable. Where $\mathrm{H} 0$ is a hypothetical assumption that has no effect, while $\mathrm{Ha}$ is a hypothetical assumption that has an effect. To test the hypothesis, a statistical test was carried out with the calculation of Structural Equation Modeling (SEM) Analysis as a quantitative analysis. According to Ghozali (2005:84) "the ttest statistic basically shows how far the influence of one explanatory/Independent variable individually in explaining the dependent variable". The hypothesis test is stated that HO is rejected or the variable has an effect if the $t$-value $>1.96$ at $a=0.05$. The following is an explanation of the relationship between each influential variable in this study.

H3 = Employee Career Development has a direct effect on Employee Performance

a. Based on the results of hypothesis testing at a $95 \%$ confidence level with a correlation value of 0.768 , it states that there is a significant influence between Employee Career Development on Employee Performance

b. This shows that the research objective is to determine the effect of Employee Career Development on Employee performance in the work environment is proven.

H6 = Employee Career Development has an indirect effect on Employee Performance

a. Based on the results of hypothesis testing at a $95 \%$ confidence level with a correlation value of 0.768 , it states that there is a significant influence between Employee Career Development on Employee Performance indirectly with moderation on Employee Satisfaction.

b. his shows that the research objective is to determine the effect of Employee Career Development on Employee performance in the work environment is proven.

H7 = Employee Satisfaction has a direct effect on Employee Performance

a. Based on the results of hypothesis testing at a $95 \%$ confidence level with a correlation value of 0.755 , it states that there is a significant influence between Employee Satisfaction on Employee Performance directly,

b. This shows that the research objective is to determine the effect of Employee Satisfaction on Employee performance in the work environment is proven.

\section{References}

[1] Alwi, S., (2001). Human Resource Management, Strategy. Competitive advantage. Yogyakarta: BPFE UGM.

[2] Arikunto, S. (2010). Research Procedure: A Practical Approach. Jakarta: Rineka Cipta.

[3] As'ad, (2003). Effective Leadership in the Company. 2nd ed. Yogyakarta: Liberty.

[4] Bernardin and Russell (Ruky's Translation). 2015. Human Resource Management, PT. Refika Aditama, Bandung.

[5] Brahmasari, IA \& Suprayetno, A., (2008). The Influence of Work Motivation, Leadership and Organizational Culture on Employee Job Satisfaction and Its Impact on Company Performance (Case Study at PT. Pei Hai International Wiratama Indonesia). Journal of Management and Entrepreneurship, 10(2), pp. 124-135. 
[6] Colquitt, JA, LePine, JA \& Wesson, MJ, (2011). Organizational Behavior. New York: McGraw-Hill.

[7] Cooper and Schindler. (2014). Bussiners Research Method. New York: McGrawHill

[8] Dessler, Gary. 2010. Human Resource Management, Volume 1. Issue 13. Linguist : Eli Tanya. Jakarta: PT. Gramedia Group Index.

[9] Hair et. al (2014). Partial least squares structural equation modeling (PLS-SEM) An emerging tool in business research. European Business Review

[10] Handoko, T Hani. 2000. Fundamentals of Production and Operations Management, Edition 1. Yogyakarta : BPPE

[11] Hartono, J. (2013). Portfolio Theory and Investment Analysis, Eighth Edition. BPFE.

[12] Hasibuan, MS, (2003). Human Resource Management. Revised ed. Jakarta: Earth Literacy.

[13] Hopman et al (2020) Managing Covid - 19 in low and middle income countries.

[14] Keban, YT, (2004). Six Strategic Dimensions of Public Administration, Concepts, Theories and Issues. Yogyakarta: Gava Media.

[15] Luthans, F., (2006). Organizational behavior. 10th ed. Yogyakarta: PT. Andi.

[16] Lohman, 2003, "Quantitative Analysis", Jogjakarta.

[17] Mahsun, M., (2006). Public Sector Performance Measurement. Yogyakarta: BPFE Publisher.

[18] Mangkunegara, AAP, (2013). Human Resource Management. Company.. Bandung: Youth Rosdakarya.

[19] Misbahuddin, \& Hasan, I. (2013). Research Data Analysis with Statistics. Bogor: Earth Literacy.

[20] Ndraha, T., (2005). Organizational Culture Theory. Jakarta: Rineka Cipta.

[21] Osborne, David \& Peter Plastic. (2000). Trimming the Bureaucracy: Five Strategies Towards [22] [23] Entrepreneurial Governance (Ramelan Abdul Rosyid Translation), Jakarta: PPM.

[24] Palan, R. (2007) Competency Management: Technical Implementation of CompetencyBased HR [25] Management to Improve Organizational Competitiveness. PPM. Jakarta.

[26] Rivai, V., (2006). Leadership and Organizational Behavior. Jakarta: Rajawali Press.

[27] Rivai, V. \& Basri, AFM, (2005). Performance Appraisal: The Right System To Assess Employee

[28] Performance and Improve Company Competitiveness. Jakarta: PT RajaGrafindo Persada.

[29] Robbins, SP, (2002). Principles of Organizational Behavior. Jakarta: Erlangga.

[30] Samsudin, Sadili. 2009. Human Resource Management. Bandung: CV Setia Pustaka.

[31] Siagian, SP, (2014). Human Resource Management. Jakarta: Earth Literacy.

[32] Simamora, B., (2003). Unpacking the Black Box of Consumer Behavior. Jakarta: PT. Main Library Gramedia.

[33] Sinambela, Lijan Poltak. 2016. Public Service Reform Theory, Policy and Implementation, PT. Earth Literacy, Jakarta.

[34] Sudarmanto, (2009), Performance and Competency Development of Human Resources, Student Library Publisher, Yogyakarta.

[35] Steers, R. \& Porter, LW, (2003). Motivation and Work Behavior. New York: McGrawHill Book Company.

[36] Sutrisno, Edy. (2011). Human Resource Management, Jakarta: Kencana 
[37] Tika, MP, (2008). Organizational Culture and Company Performance Improvement. 2nd ed. Jakarta: Earth Literacy.

[38] Umam, K., (2010). Organizational behavior. Bandung: Faithful Library.

[39] Wibowo, TA, (2008). Analysis of the Influence of Organizational Culture and Job Satisfaction on Employee Motivation and Performance (Study at the BRI Pattimura Branch Office, Semarang). Semarang: Master of Management at Diponegoro University.

[40] Wirawan, (2007). Organizational Culture and Climate. Jakarta: Four Salemba.

[41] Wirawan, (2009). Evaluation of Human Resource Management Performance. Jakarta: Four Salemba.

[42] Wirawan, (2015). Indonesian Human Resource Management: Theory, Psychology, Employment Law, Applications and Research: Applications in Business Organizations, Government and Education. Jakarta: Rajawali Press.

[43] Ivancevich, JM, Konopaske, R. \& Matteson, MT, (2007). Organizational Behavior and Management. Jakarta: Erlangga Publisher. 